\title{
RRAS Gene
}

National Cancer Institute

\section{Source}

National Cancer Institute. RRAS Gene. NCI Thesaurus. Code C106070.

This gene is involved in both axon guidance and the promotion of angiogenesis. 